\title{
Z PROBLEMATYKI CELOWOŚCI W BIOLOGII
}

\section{Uwagi wstępne}

Zagadnienie celowości w przyrodzie stanowi problem trudny, stawiany już u początków filozoficznej myśli. W starożytności sformułowano dwa przeciwstawne sobie modele, mianowicie celowości i przypadkowości ${ }^{1}$. Dzisiaj pojęcie celowości posiada olbrzymie znaczenie nie tylko dla filozofii, lecz także dla nauki. Równocześnie należy do pojęć spornych, ponieważ wchodzą tu w grę rozmaite przeciwstawne postawy, oraz epistemologiczne i ontologiczne założenia ${ }^{2}$. Nie zajmując się przeszłymi sporami o celowość, spróbujemy przedstawić to zagadnienie tak, jak przedstawia się ono u niektórych współczesnych biologów ${ }^{3}$.

Zagadnienie celowości w przyrodzie poczęto dyskutować w filozofii, gdy powstało pytanie: „,dlaczego”. Dawniej uważano, że pytanie to należy wyłącznie do dziedziny filozofii. Klimat tego zagadnienia zmienił się we współczesnej biologii, która również stawia pytania: „dlaczego”. Pytanie to nie ma miejsca w fizyce, pisze $\mathrm{K}$. Lorenz, lecz byłoby mylnym iść za fizykalnym poznaniem i wyłączać to pytanie z biologii. Pytanie to dotyczy bowiem celowości biologicznych zjawisk i daje wyraz temu, że struktury i funkcje organizmu należy pojmować jako będące w służbie utrzymania gatunku czy systemu. Pytanie „dlaczego" można wykluczyć z biologii tylko na bazie mechanicyzmu ${ }^{4}$.

Podobne stanowiska zajmuje u nas T. Ścibor-Rylska, według której dla pełnego obrazu życia brakuje czegoś, ponieważ człowiekowi nie wystarcza poznanie jedynie fizyko-chemiczno-cybernetycznych aspektów życia. Dla uchwycenia sensu organizowania się układu trzeba jeszcze odpowiedzieć na dwa pytania: „dlaczego” i „po co”. W ten sposób dochodzimy do problemu celowości, nie wiadomo czy słusznie rezerwowanego dotychczas dla filozofii ${ }^{5}$. W ten sam

${ }^{1}$ R. Spaemann, R. Löw, Die Frage - wozu?, München-Zürich 1981, s. 27 nn.

2 P. Lenartowicz TJ, Analiza pojęcia wycelowania wewnętrznego, „Studia Philosophiae Christianae" $16: 1980$ s. 39.

${ }^{3}$ Historię zagadnienia przedstawiają Spaemann i Löw (jw., s. 27 - 233).

${ }^{4} \mathrm{~K}$. L o r en z, Vergleichende Verhaltungsforschung. Grundlagen der Ethologie, Wien-New York 1978, s. 25.

${ }_{5}^{5}$ T. Ścibor-Ryls k a, Tajemnice uorganizowania żywej komórki, Warszawa 1986, s. 473. 
sposób wyraża się P. P. Grassé, że biolog staje wobec problemu celowości i niesłusznie pozostawia się go metafizyce ${ }^{6}$.

Problem celowości, pisze F. Wuketis, przysporzył wiele kłopotów w naukach biologicznych. Od czasu Arystotelesa celowość, czyli teleologia, stanowiła podstawową zasadę życia, a i dzisiaj problematyka ta odgrywa ogromną rolę. Pytania tego nie można wyprzeć dziś z biologii, ponieważ ten sposób pytania podkreśla swoistość biologicznego poznania i swoistość metod poznawczych przyrodoznawstwa. Za E. Naglem ${ }^{7}$ Wuketis przyjmuje, że wszystkie wyjaśnienia w nauce są odpowiedziami na pytanie: „dlaczego”. Każda bowiem odpowiedź na nie jest wyrazem dążenia do wyjaśniania nowego zjawiska przez włączenie go w system znanych związków i stawiania go w wyższe ramy odniesienia. Taki punkt widzenia celowości nie wiąże się zdaniem Wuketisa, ani $\mathrm{z}$ witalizmem, ani $\mathrm{z}$ redukcjonizmem ${ }^{8}$.

W biologii XX w., pisze Wuketis, zaczęto na nowo zdawać sobie sprawę, że inaczej niż w bytach nieorganicznych, punkt widzenia celowości jest istotny w biologii. Równocześnie biologowie zdają sobie sprawę z tego, że nic, względnie tyle co nic, osiągnie się przez ucieczkę do niejasnych wypowiedzi witalistów i finalistów. Z drugiej strony Wuketis podkreśla, że nie spełni się optymizm Haeckla, iż nie istnieje żadna celowość w przyrodzie ${ }^{9}$. Za czasów Darwina wierzono, że teoria selekcji stanowi ostateczny argument przeciw teleologii. Tymczasem w XX w. odżyła debata na ten temat, ponieważ biologowie uświadomili sobie, że używając takich pojęć, jak funkcja, przystosowanie, samoregulacja, samoreprodukcja, nieświadomie posługują się finalistyczną terminologią ${ }^{10}$.

Tak więc klimat wobec zagadnienia celowości w biologii zmienił się ostatnio na jego korzyść, choć nie w pełnym jego tradycyjnym znaczeniu. Św. Tomasz przyjmował za Arystotelesem, że cała natura, a nie tylko człowiek, działa celowo. Według Akwinaty coś dąży do celu swym działaniem albo poruszając samego siebie, jak to czyni człowiek, albo jako poruszany przez drugiego do celu, jak np. strzała. Byty rozumne dążą do celu same, natomiast byty pozbawione rozumu dążą wprawdzie do celu przez swoją naturalną skłonność, lecz jako poruszane przez drugich. Przy czym natura nierozumna dąży do celu albo jako poznanego, jak to czynią zwierzęta, albo jako do celu niepoznawanego, jak to czynią byty nie posiadające w ogóle poznania ${ }^{11}$. Według św. Tomasza cel jest wprawdzie ostatni w wykonaniu, lecz jest pierwszy w intencji działającego i jako taki jest $z$ tej racji przyczyną ${ }^{12}$. Działanie celowe poniżej rozumu posia-

${ }^{6}$ P. P. G ras sé, Das Ich und die Logik der Natur, München 1973, s. 10.

${ }^{7}$ R. N a gel, Struktura nauki, Warszawa 1961, s. 23. 79,135

${ }^{8}$ F. Wuk et is, Biologische Erkenntnis. Grundlagen und Probleme, Stuttgart 1983, s. $77-$

${ }^{9}$ Tenże, Zustand und Bewusstsein, Hamburg 1985, s. 175.

10 Tamże, s. 172.

${ }^{11} \mathrm{~S}$. Th om as de Aquino, Summa theologiae, IaII ${ }^{\mathrm{ae}}$ a. $2 \mathrm{c}$.

${ }^{12}$ Tamże, $I^{\mathrm{a}} \mathrm{II}^{\mathrm{ae}}$ a. 1. ad. 1. 
da swą przyczynę w rozumie Stwórcy, który dał bytom takie właściwości, że nieświadomie realizują myśl Absolutu. Dostrzegali to, pisze A. M. Krąpiec, już starożytni filozofowie greccy, którzy w uporządkowanym działaniu kosmosu widzieli działanie Logosu13. Myśli Arystotelesa i św. Tomasza o celowości zaczynają przejawiać się w dyskusjach współczesnych biologów.

Obraz nauki, pisze L. V. Bertalanffy, przeszedł zmiany w ciągu kilkudziesięciu lat. Mechanicystyczna teoria, zrodzona $\mathrm{z}$ dziewiętnastowiecznej fizyki klasycznej, tłumaczyła wszystkie zjawiska bezcelową grą atomów, którymi rządzą prawa przyczynowości, wywołujące wszystkie zjawiska w świecie nieożywionym, ożywionym, a także umysłowym. W mechanicyzmie brak jest miejsca na ukierunkowanie, ład i celowość. Świat organizmów jawił się jako produkt przypadku, który powstał $\mathrm{z}$ bezsensownej gry losowych mutacji i działania naturalnego doboru. Swiat umysłowy jest dziwnym, raczej niekonsekwentnym epifenomenem materialnych zdarzeń. Dlatego pojęcia teleologii i kierunkowości znalazły się poza zasięgiem nauki, stały się pseudoproblemem obcym nauce i były uważane za fałszywą projekcję ludzkiego umysłu w przyrodę, rządzoną przez bezcelowe prawa.

Według Bertalanffiego charakterystyczne dla obecnych poglądów jest to, że aspekty celowości i kierunkowości traktuje się poważnie, jako pełnoprawny problem dla nauki. Do przyjęcia takiego poglądu skłaniają według niego trzy biologiczne modele: Pierwszy to ekwifinalnóść, czyli tendencja do osiągania charakterystycznego końcowego stanu wychodząc $\mathrm{z}$ różnych stanów początkowych, oraz dążenie do celu różnymi drogami, opartymi na dynamicznej interakcji w systemach otwartych. Drugi model to sprzężenie zwrotne, oparte na zwrotnych łańcuchach przyczynowych i mechanizmach przekazujących informację dotyczącą odchyleń od stanu, który trzeba utrzymać, czy celu, który trzeba osiągnąć. Trzecim jest model przystosowania, który wyznacza sposoby adaptacyjnego zachowania się. Dlatego Bertalanffy uważa, że teleologiczne zachowanie, skierowane ku charakterystycznemu końcowemu stanowi lub celowi, nie stwarza błędnej antropomorficznej koncepcji procesów, które same w sobie jakoby miały być nie ukierunkowane i przypadkowe, a przez to nie leży poza zasięgiem nauk przyrodniczych. Jest to raczej forma zachowania się organizmów, którą można definiować przy użyciu naukowej terminologii i dla której można wskazać niezbędne warunki i możliwe mechanizmy ${ }^{14}$.

Tak więc ustają dziś spory o celowość w biologii, natomiast powstaje dyskusja o jej zasięg oraz o jej rozumienie. Wiąże się to $\mathrm{z}$ wprowadzonymi pojęciami teleonomii i teleologii czyli ogólniej finalizmu. Przyczynę tego rozróżnienia widzi Lorenz w dziwnym konflikcie, w jaki popada przyrodnik, gdy z jednej strony podziwia genialną konstrukcję ewolucji, a z drugiej jest rozczarowany, gdy

13 A. M. Kr ąpie c, Metafizyka, Poznań 1966, s. 166- 174.

${ }^{14} \mathrm{~L}$. van B er t a l a n f y, Ogólna teoria systemów, Warszawa 1984, s. 76- 78. 
widzi, ile niecelowości wykazują ewolucyjne generacje. Celowość budowy i zachowania się każdej żywej istoty jest widoczna w dążeniu do możliwie bogatego potomstwa, czyli do przeżycia gatunku. Pytanie o celowość utrzymującą gatunek nazywa Lorenz wraz z innymi biologami pytaniem teleonomicznym. Natomiast pytanie o sens istnienia i kierunkowości całej ewolucji nazywa pytaniem teleolgicznym ${ }^{15}$. Według Wuketisa telenomiczne są wszystkie struktury i funkcje organizmu służące do utrzymania gatunku. Wyjaśnienia teleologiczne wychodzą poza te funkcjonalne wyjaśnienia i zakładają uniwersalną celowość ${ }^{16}$. Sam termin „teleonomia” wprowadził amerykański etolog C. S. Pittendrigh (1958), aby odróżnić celowość w obrębie gatunku od teleologii jako celowości całej biosfery ${ }^{17}$.

Naleźy dodać, że są i dziś biolodzy, którzy odrzucają wszelką celowość w przyrodzie. I tak E. Jantsch uważa, że świat jest nie tylko nieteleologiczny, lecz także nieteleonomiczny. Pojęciu samoorganizacji nie odpowiada ani stare wyobrażenie teleologicznej ewolucji, ani jego modyfikacja w sensie ewolucji teleonomicznej. Świat nie posiada żadnego celu ${ }^{18}$. Podobnie S. E. Luria pisze, że precyzyjne działanie systemu chemicznej katalizy i jej regulacji sprawia wrażenie, jakoby biochemiczne mechanizmy działały teleonomicznie. Jest to jednak celowość tylko pozorna, całe działanie pochodzi od naturalnej selek$\mathrm{cji}^{19}$.

\section{PROBLEMATYKA TELEONOMII W ORGANIZMACH}

Dzisiaj prawie wszyscy biologowie przyjmują istnienie teleonomicznych procesów w żywych organizmach niezależnie od tego, jak je rozumieją i czy używają tych samych nazw. Nawet tak skrajni redukcjoniści jak J. Monod, pisze W. H. J. Kunicki-Goldfinger ${ }^{20}$; przyjmują teleonomię. Jako trzy fundamentalne cechy życia Monod wymienia teleonomię, która orzeka, że wszystkie żywe organizmy są wyposażone w plan, autonomiczną morfogenezę, dzięki której wszystkie organizmy rozwijają się autonomicznie i spontanicznie, oraz inwariantną reprodukcję, dzięki której wszystkie organizmy mogą przekazywać informację swemu potomstwu. Według Monoda poziom teleonomiczny

${ }^{15}$ K. Lor enz, Der Abbau des Menschlichen, München-Zürich 1986, s. 27 n.

${ }^{16} \mathrm{~F}$. Wu ket is, Biologische Erkenntnis..., s. 123 - 124; tenże, Evolution, Erkenntnis, Ethik, Darmstadt 1984, s. 55.

${ }_{17}$ Tenże, Biologische Erkenntnis..., s. 124.

${ }^{18}$ E. J a n t s ch, Die Selbstorganisation des Universum, München 1982, s. 21, 253, 348.

${ }^{19}$ S. E. Luri a, Leben - das unvollendete Experiment, München-Zürich 1973, s. 109 n. Kłopoty, jakie mają biologowie $\mathrm{z}$ celowością, oddają słowa $\mathrm{F}$. B a c on a (De dignitate et augmentis scientiarum, III 5): „[...] nam causarum finalium inquisitio sterilis est, et tanquam virgo Deo consecrata, nil parit" (cytuje za: Spa emann, Löw, jw., s. 23). Natomiast Wu ke tis (Zustand..., s. 172) przytacza słowa J. S. Haldana, że teleologia jest dla biologa jak metresa, bez której nie może żyć, lecz z którą nie chce się pokazywać publicznie.

20 W. H. J. Kunicki-Goldfinger, Wartości w pracy badawczej przyrodnika, „Przegląd Powszechny" 3:1987 s. 360 n. 
danego gatunku odpowiada ilości informacji, która winna być przeniesiona na potomstwo dla zapewnienia gatunkowi ciągłości przez reprodukcję i inwariancję. Działaniem teleonomicznym są także procesy przystosowawcze do otoczenia. Organizm żywy realizuje plan, który wynika z jego wewnętrznej organizacji, a nie jest nadany $z$ zewnątrz ${ }^{21}$.

Według B. Renscha przedziwna celowość, która wyraża się w budowie i życiu wszystkich organizmów, jest wytłumaczalna całkowicie przyczynowo. Wszystkie bowiem prawa i reguły biologiczne opierają się ostatecznie o procesy przyczynowe i dlatego, wbrew twierdzeniu witalistów, nie ma potrzeby przyjmowania szczególnych praw celowości, które miałyby nakierowywać procesy na cel. Nie potrzeba też, jak to zakłada wielu witalistów, przyjmować pełnej tajemnicy kierującej zasady, ani stwórczej siły dla powstania organizmów. Godna podziwu celowość w budowie i funkcji żywych organizmów jest zrozumiała przez stałe działanie doboru, który utrzymuje wszystkie ważne strukturalnie i funkcjonalnie procesy. Nie ma przeto powodu przyjmować szczególnych kształtujących ewolucyjnych sił czy zakładać stwórczą czynność Boskiej Istoty 22 .

Lorenz uważa, że celowość budowy ciała i zachowania się każdej żywej istoty kieruje się wyłącznie, co można wykazać, na wydanie moóliwie licznego potomstwa i więcej nic. Pytanie o utrzymującą gatunek celowość jest pytaniem teleonomicznym, w przeciwieństwie do pytania teleologicznego o sens istnienia $^{23}$. Wielu ludziom, pisze Lorenz, wydaje się niemożliwym, żeby istniały we wszechświecie.procesy, które nie byłyby ukierunkowane ku pewnym celom. Przyczynę takiego poglądu upatruje Lorenz w obawie ich o to, żeby w przypadku braku celu nie okazała się iluzoryczną wolność woli ludzkiej. Jednakże celowo ukierunkowane procesy są dane w kosmosie wyłącznie w zakresie organizmów żywych ${ }^{24}$. Również wszelkie procesy uczenia się uważa Lorenz za teleonomiczne modyfikacje tych fizjologicznych mechanizmów, które sterują zachowaniem się organizmów ${ }^{25}$.

Swe rozważania o celowości w przyrodzie poprzedza P.P. Grassé określeniem, co rozumie przez pojęcie natury. Naturą jest według niego całość wszystkich materialnych ożywionych i nieożywionych przedmiotów, z których składa się wszechświat, oraz prawa którym podlega i dzięki którym stanowi uporządkowaną całość. Materialistycznie nastawieni biologowie stwierdzają istnienie porządku w naturze, natomiast odrzucają interpretację tego porządku przy pomocy zasady celowości, wychodząc z zalożenia, że determinizm i finalizm nie

21 J. Monod, Le hasard et la nécessité, Paris 1970, s. 26-33.

22 B. R e n s h, Das universale Weltbild. Evolution und Naturphilosophie, Frankfurt am Main 1977 , s. 66, $100-101,276$.

${ }_{23}^{3}$ K. Lorenz, Der Abbau..., s. 28 s. 24.

24 Tenże, Das Wirkungsgefüge der Natur und das Schicksal des Menschen, München 1983,

${ }^{25}$ Tenże, Die Rückseite des Spiegels, München 1977, s. 109. 
godzą się ze sobą. Pogląd ten, chociaż bardzo rozpowszechniony, uważa Grassé za z gruntu fałszywy. Właśnie celowość nadaje determinizmowi zdarzeń charakter biegu losowo nieuniknionego, ponieważ ogranicza ściśle jego działanie a równocześnie je kanalizuje. Bez determinizmu nie można wyobrażać sobie żadnej celowości, nawet gdyby się uważało ją za rodzaj prymitywnego animizmu $^{26}$.

Przez analizę można rozkładać żywe istoty na procesy fizykochemiczne, lecz nie jest to uchwyceniem całego organizmu. Organizmy wykazują bowiem czynności, które nie są ani dowolne, ani przypadkowe, ponieważ dążą do utrzymania go i reprodukcji. To dążenie świadczy, że istoty żywe posiadają w sobie wewnętrzną celowość, która wyraża się w mechanizmie samozachowania się, wewnętrznej asymilacji i rozrodu. Przyjmując tego rodzaju celowość, nie implikuje się jakiegoś filozoficznego stanowiska, nie zakłada się ani świadomości, ani transcendencji. Ta wewnętrzna celowość zdaje się być nowym ewolucyjnym osiągnięciem, które zostało wprowadzone do świata przez powstanie żywych istot ${ }^{27}$.

Immanentna biologiczna celowość, pisze Grassé, nie jest jakąś tajemniczą zasadą, nie jest bergsonowskim elan vital czy entelechią, ani nie jest niematerialną przyczyną działającą z zewnątrz, lecz jest podstawową własnością żywych organizmów i nie będzie przesadą powiedzieć, że jest ona samym życiem $^{28}$. Biologiczna celowość nie polega tylko na przystosowaniu organów do ich funkcji, lecz jest dana w samym życiu i wyraża się nie tylko przez świadome akty woli, lecz także działa bez udziału świadomości. Słownik biologów i biochemików opisujący struktury i funkcje makrodrobin jest w wysokim stopniu finalistyczny. Piorunuje się przeciw celowości, pisze Grassé, wyraża się wstręt do niej i potępia się ją, a równocześnie przeprowadza się eksperymenty i badania w sensie finalizmu ${ }^{29}$.

Zwolennicy teorii przypadku, pisze Grassé, wierzą, że będą mogli wykazać, że nie ma celowości w naturze, a nie widzą, źe przy tym przypisują jej implicite transcendentalną celowość, ponieważ wybór alternatyw jest zawsze związany z przyczynami celowymi. W rzeczywistości przesuwają celowość aż do jej ostatecznych granic. W ich teorii transcenduje przeto zasada celowości daleko poza biologiczny świat, aż do świata metafizyki. Tak więc antyfinalizm posiada daleko sięgające konsekwencje, bo prowadzi znów do finalizmu. Musimy przyznać uczciwie, pisze obrazowo Grassé, że celowość jest jak chwast w przyrodoznawstwie, zaledwie wypleni się go w jednym miejscu, wyrasta jeszcze silniej w innym. Wyprze się go $\mathrm{z}$ jednej dziedziny, to rozszerza się jeszcze potężniej w innej. Szybciej niż Feniks powstaje na nowo z popiołów ${ }^{30}$.

\footnotetext{
${ }^{26}$ P.P. Gross é, Das Ich..., s. 38 n.

27 Tamże, s. 44n.

${ }^{28}$ Tamże, s. 45 .

29 Tamże, s. 49.

30 Tamże, s. 54.
} 
J.-L. Parrot uważa, że negować istnienie celowości to tyle samo, co negować fakty. Przyjmując jednak fakt celowości w rozumieniu teleonomii, równocześnie odrzuca finalizm w rozumieniu teleologii. Niektórzy filozofowie i fizjologowie przejawiają kompleks antyfinalistyczny i używają różnych słów, aby wstydliwie zakryć celowość. Trzy są, jego zdaniem, główne przyczyny tego antyfinalistycznego kompleksu. Pierwszą stanowi obawa popadnięcia w mglisty witalizm i finalizm (teleologia). Zdaniem Parrota finalizm narodził się nie z obserwacji, lecz z idei a priori pozaeksperymentalnej. Dlatego Parrot proponuje uznanie faktów celowości poza doktryną finalizmu, czyli celowość bez finalizmu. Drugą przyczynę kompleksu antyfinalistycznego widzi w trudności wintegrowania celowości w ramy współczesnej czterowymiarowej matematyki. Trzecią przyczynę stanowi obawa przed przesadnym przyjmowaniem celowości. Parrot uważa, że nie we wszystkim przejawia się celowość i nie jest ona ani absolutną ani doskonałą ${ }^{31}$.

Według Parrota przeciwstawianie celowości działaniu jej mechanizmów jest klasycznym błędem. Łatwo bowiem jest przyjąć i stwierdzić fakt celowości, lecz badanie mechanizmów jej działania jest trudne. Fakt celowości jest jasny, natomiast wyjaśnienie tego faktu wymaga często skomptikowanych technik. Celowość jest oczywista od razu, natomiast jej mechanizmy są często nieznane. Przejrzystość celowości przeciwstawia się nieprzeźroczystości jej mechanizmów ${ }^{32}$. Stwierdzamy, że przeżywa gatunek, lecz pozostaje do zbadania przez jakie mechanizmy broni się przed niebezpieczeństwami, które mu grożą. Do zakresu tych badań należy struktura, funkcja i zachowanie się żywej istoty, a więc fakty obserwacyjne, eksperymentalne. Fakty te są doskonale obiektywne i nie zawierają żadnej pozaeksperymentalnej idei. Jest oczywistym, że organizm nie mógłby wykonywać swych funkcji, gdyby nie dysponował strukturą zorganizowaną do tego celu. Biologiczna celowość jest dana faktycznie i jest związana z samą naturą życia. Byty nie istniałyby, gdyby nie były rządzone celowością. Nie ma życia bez dążności do utrzymania się, do adaptacji i prokreacji. Pojęcie celowości posiada wielką heurystyczną wartość i często pozwala na ukierunkowanie sposobów eksperymentowania. Dlatego biolog mówiąc o celowości nie jest metafizykiem, ponieważ stawia ten problem na płaszczyźnie biologicznej, eksperymentalnej ${ }^{33}$.

Celowość oskarżana przez tradycję wywodzącą się od Demokryta, później Kartezjusza, przeżyła według $\mathrm{H}$. Barreau pod różnymi formami. Wspólnym dla klasycznego finalizmu i neofinalizmu jest to, że nie można badać żywych istot takimi samymi pojęciami, jakich używa klasyczna fizyka. Zdaniem Barreau przeciwnicy finalizmu winni zrozumieć, że organizmy wykazują bezdys-

31 J. L. P a r r ot, Essai de définition, [w:] La fin et les moyens études sur la finalité biologique et ses mécanismes, Paris 1985, s. 20 - 22.

${ }_{32}$ Tamże, s. 37.

${ }^{33}$ Tamże, s. $40-42$. 
syjnie cechy celowości. Również Darwin nie zaprzeczał celowości, a tylko uważał, że adaptacja wyjaśnia celowość, a nie odwrotnie. Dlatego sądzil, że celowość zasługuje na wyjaśnienie. Według Barreau w wyjaśnianiu celowości uczeni dzielą się na dwa obozy: Jedni uważają, że nauka jest materialistyczna, a materializm jest deterministyczny i determinizm wyjaśnia mechanizmy, które kierowały narodzinami celowościowych organizmów. Drudzy sądzą przeciwnie, że jest nieuzasadnionym odwracanie się od celowości, ponieważ pomaga ona czynić znaczne postępy w przybliżaniu się do poznawania zjawisk ważnych dla życia i jego początku ${ }^{34}$.

Również G. Bernardi opowiada się za istnieniem celowości faktycznej, bez przyjmowania celowości ogólnej. Jego zdaniem słowo „celowość” bez dalszego określenia prowadzi do nieporozumień, ponieważ korzenie tego słowa są takie same jak finalizmu, który jest doktryną sprzeciwiającą się mechanicyzmowi. Finalizm zakłada ukierunkowanie, intencję czy świadomość osiągania celu. Aby uwolnić to słowo od wszelkiej, jak to ujmuje Bernardi, teistycznej interpretacji, przynajmniej na poziomie zjawisk bezpośrednio badanych, lepiej jest mówić za L. Cuénotem o celowości faktycznej czy organicznej, jako przeciwstawnej intencjonalnej celowości ludzkiej względnie opatrznościowej. Dlatego według Bernardiego należy odrzucić słowo „teleologia”, pozostawić na boku słowo „teleonomia” na rzecz wyrażenia „celowość faktyczna”35.

F. Boitel uważa, że Leibnizowska zasada wystarczającej racji wyraża się w dwóch formach: $Z$ jednej strony chcę odpowiedzieć na pytanie, co jest przyczyną sprawczą, a z drugiej pyta „dlaczego”, czyli pyta o przyczynę celową, po prostu o celowość. Z analizy paleontologicznych zjawisk Boitel wyciąga wniosek, że obie strony tej zasady mogą być rozumiane zarówno pod formą przyczynowości sprawczej, jak i pod formą celowości. Faktyczna przyczynowość sprawcza odpowiada w sposób symetryczny i wewnętrzny celowości faktycznej. Status epistemologiczny zasady wystarczającej racji rozważany pod aspektem celowości faktycznej nabiera szerszego znaczenia i może być rozważany pod względem formalnym i dynamicznym jako wektor. Aspekty przyczynowości sprawczej i celowości faktycznej nie są sprzeczne, lecz są komplementarne ${ }^{36}$.

Y. Leroy, inny francuski biolog, przyjmuje także celowość faktyczną w biologii. Również według niego odwoływanie się do celowości faktycznej posiada wartość heurystyczną, co nie jest bez znaczenia dla badawczych metod. Natomiast źle zastosowana i niekontrolowana stale faktami, może prowadzić do fałszywych rozumowań. Studium celowości faktycznej prowadzi do ujęcia świata ożywionego naraz z punktu widzenia statycznego i ewolucyjnego. Tego rodza-

${ }^{34} \mathrm{H}$. B a r r e a u, La problematique de la finalité dans l'histoire de la pensée occidentale, [w:] La fin et les moyens études..., s. 56.

${ }_{35} \mathrm{G}$. B e rn a $\mathrm{rdi}$, Les théories explicatives du mimétisme batésien chez les insectes Lépidoptéres et les mécanismes de la finalité, [w:] La fin et les moyens études..., $\mathrm{s} .141 \mathrm{n}$.

${ }^{36} \mathrm{~F}$. B o it $\mathrm{e}$, Comment peut-on penser la finalité de fait et paléontologie?, [w:] La fin et les moyens études..., s. $75,86-88$. 
ju celowość faktyczna jest ograniczona do ewolucji biologicznej. Można by przyjąć inną celowość $\mathrm{w}$ dziedzinie fizyki i astronomii, prawdopodobnie według innych czasoprzestrzennych norm, jednakże tak stawiając zagadnienie opuszcza się ramy celowości faktycznej w biologii ${ }^{37}$.

Według H. Sachse pytanie, czy procesy natury posiadają określony kierunek, czy dany jest cel i jaki jest ten cel, stanowi pytanie zarówno naukowe jak i filozoficzne. Człowiek stoi bowiem pośrodku zdarzeń i pytanie o własny sens życia jest złączony z pytaniem o cel całości świata. Pierwszą szczegółową odpowiedź na pytanie o kierunek procesów natury dał Arystoteles na podstawie obserwacji natury. Jego odpowiedzią była teoria hylemorfizmu, według której wszystko porusza się w określonym kierunku, dąży do zajęcia własnego naturalnego miejsca. Znaczy to, że wszystkie zmiany są kierowane do celu, który jest włożony w formy substancjalne zmieniających się rzeczy. Dla tej określającej kierunek formy przyjął nazwę entelechia (urzeczywistnianie celu). Każdy byt materialny posiada formę, a więc określone przeznaczenie. Kartezjusz uważał ożywione byty poniżej człowieka za maszyny. Korzyści płynące z takiego ujęcia były te, że wyjaśnienie stawało się proste, oglądowe i wyrażalne matematycznie. Straty płynące z tego ujęcia były te, że w mechanice nie ma uprzywilejowanego kierunku ${ }^{38}$. Arystoteles wprowadził obok przyczyny sprawczej przyczynę celową. Ale już w starożytności wysuwano zastrzeżenia, które spotykamy u Lukrecjusza. W historii kultury spór o celowość odgrywa aż do dzisiejszych czasów ogromną rolę. Trudno o zgodę pomiędzy autorami, ponieważ wchodzi tu w grę czynnik światopoglądowy ${ }^{39}$.

W rozważaniach swych wychodzi Sachse od wyjaśnienia stosunku przyczyny celowej do sprawczej. Przyczynowość sprawcza powoduje, że w przebiegu zdarzeń określone stany posiadają z konieczności określone następstwa. Przyczyna celowa sprawia, że procesy osiągają stan końcowy, który jest założony przez stan początkowy. Zgodnie $\mathrm{z}$ tego rodzaju rozumieniem ze ścisłej przyczynowości sprawczej wynika logicznie celowość i odwrotnie. Jeżeli przebieg zdarzeń jest deterministyczny, to za stanem początkowym musi iść stan końcowy i odwrotnie. Między stanami $t_{1}$ oraz $t_{2}$ istnieje wzajemna implikacja, wzajemne konieczne uwarunkowanie i zależność, a jedna da się wyliczyć z drugiej. Pojęcia przyczynowości sprawczej i celowość są w takim stosunku do siebie, że można pominąć jedno a trzymać się drugiego. Sachse twierdzi, że niesłuszna jest teza, że celowość zakłada świadomość jako warunek początkowy, aby cel został osiągnięty, ponieważ ustalone w jakikolwiek sposób warunki początkowe prowadzą do określonego celu ${ }^{40}$.

37 Y. Le roy, Communication animale et finalité de fait, [w:] La fin et les moyens études..., s. $126-129$.

${ }^{38} \mathrm{H}$. S a c h se, Über die Richtung der Naturprozesse, [w:] Wir sind Evolution, hrsg. von G. K. Kalt enbrunner, München 1981, s. 13, 15-17.

${ }_{39}$ Tenże, Kausalität - Gesetzlichkeit - Wahrscheinlichkeit, Darmstadt 1979, s. 13.

${ }^{40}$ Tamże, s. 13, 14, 18. 
F. Wuketis przez teleonomię rozumie wszystkie struktury, względnie funkcje żywej istoty, które posiadają zdolność utrzymania gatunku. Optymalizacja genetycznego programu dokonuje się w procesie naturalnego doboru. Ewolucja nie operuje ukierunkowanym działaniem na możliwe cele, lecz jest grą w danych warunkach i dąży tylko do bezpośredniego celu, mianowicie do przeżycia gatunku. Celowy związek, widoczny w strukturze, funkcji i zachowaniu się organizmu, da się sprowadzić do związku przyczynowego, rozumianego zgodnie z modelem przyczynowości funkcjonalnej. Teleonomiczne struktury są skierowane na cel, lecz kierunek celu nie jest z góry dany. Struktury te są ukierunkowane $\mathrm{z}$ uprzednio danych procesów ${ }^{41}$.

Cele rozumiane jako teleonomia przyszły na świat razem z życiem. Powstały one we wzajemnym powiązaniu protein i kwasów nukleinowych w organizacji hypercyklów Eigena. Są to cykle „bez zamysłu” (ohne Absicht), ponieważ tylko człowiek stawia cele $\mathrm{z}$ namysłem. Tego rodzaju celowość istot organicznych, w odróżnieniu od bezcelowości kosmosu i kosmicznej ewolucji, da się ustalić jako genetyczne programy powstałe wraz z hypercyklem. Bez tego rodzaju celowości organizm jest nie do pomyślenia. Teleonomia pozwala nam poznać żyjące organizmy na ewolucyjnej podstawie. Celowość ta odróżnia byty żyjące od nieżyjących. Zaprzeczać tej teleonomii byłoby przechodzeniem redukcjonizmu obok istotnej cechy żyjących systemów ${ }^{42}$. Aspekt celowości posiada wartość heurystyczną w biologicznych badaniach, gdyż wskazuje, że procesy winny być rozpatrywane także ze względu na ich końcowy stan. Przyczynowość nie przeciwstawia się celowości ${ }^{43}$.

Wuketis uważa, że odpowiedzią na pytanie o celowość w zakresie organicznych bytów może być tylko jedna: cele bez zamysłu. Procesy organiczne są niewątpliwie celowo ukierunkowane, lecz równocześnie nie dążą do celu. Określony kierunek np. embrionalnego rozwoju żywej istoty wynika $\mathrm{z}$ wytworzonego i ustalonego w dziedzicznym rozwoju genetycznego programu. Właśnie dla określenia tej formy celowości, czyli czystego ukierunkowania, przyjęto dziś termin „teleonomia”. Tak więc przez teleonomię rozumiemy działanie według planu wynikającego z genetycznego programu, działanie celowe, lecz bez poznania celu. Przy czym wszystkie struktury i funkcje organizmu są teleonomiczne. Wszelkie zaś zachowanie się organizmu żyjącego służy zachowaniu gatun$\mathrm{ku}^{44}$.

T. Ścibor-Rylska w początkowej fazie swych poglądów szła za koncepcją ks. K. Kłósaka, że celowe działanie jest właściwe tylko człowiekowi, względnie zwierzętom obdarzonym wyższym psychizmem, natomiast $w$ reszcie świata

\footnotetext{
${ }^{41}$ F. Wuketis, Evolution..., s. $55-57$.

42 Tamże, s. $183-186$.

43 Tenże, Biologische Erkenntnis..., s. 126.

${ }^{44}$ Tenże, Zustand..., s. 175 n.
} 
jedynie „coś się dzieje”. Przypisywanie komórce zdolności do celowego działania byłoby czystym antropomorfizmem. Jednakże w miarę rozwoju nauk biologicznych, pisze Rylska, pojawia się tendencja do mnożenia wyrażeń o celowościowym działaniu w organizmach żywych. W działalności komórek można znaleźć wiele dowodów na celowość składu, budowy i działania ich produktów. Rylska rozróżnia cele wewnętrzne i zewnętrzne komórki. Celem wewnętrznym jest podtrzymywanie życia, stan uorganizowania i negentropii. Cele zewnętrzne to rozmnażanie, podział komórki, wytwarzanie substancji odżywczych, pochłanianie bakterii. Realizacja tych celów jest warunkiem życia. Działaniem celowym nazywa Rylska wszelkie działanie układu posiadającego własną wewnętrzną informaçję o celu jako celu i zdolnego do wybierania środków prowadzących do tego celu ${ }^{45}$.

\section{SPÓR O TELEOLOGIE,}

O ile powszechnie biologowie zajmują pozytywne stanowisko wobec procesów teleonomicznych w organizmach, o tyle dzielą się w poglądach na celowość całej biosfery. Jedni odrzucają ją, inni zajmują wobec niej umiarkowane stanowisko. Przeciw celowości obejmującej cały ewolucyjny rozwój stanowczo wypowiada się Lorenz. Według niego fakt, że w indywidualnym rozwoju istoty żywej zachodzą rzeczywiste celowe procesy jako urzeczywistnienie danego uprzednio planu, bardzo łatwo prowadzi do przekonania, że to samo jest ważne dla całego ewolucyjnego rozwoju biosfery. Już samo słowo ewolucja, rozwój jest bliskie temu wyobrażeniu. Jednakże próba winterpretowania sensu i kierunku rozwoju w ewolucję całej biosfery jest według niego tak samo chybiona, jak usiłowania badaczy, by z historycznych procesów przewidzieć dalszy bieg historii. Na dowód braku celowości w ewolucyjnym rozwoju przytacza Lorenz szereg tzw. „błędów” ewolucji ${ }^{46}$. Woda płynie zawsze naprzód, pisze, natomiast rozwój życia w żadnym przypadku nie idzie naprzód i nie posiada w sobie żadnej takiej tendencji. Nie istnieje ogólna kierunkująca tendencja, jest tylko gra niezliczonych wzajemnych działań, które sprawiają organiczne stawanie się ${ }^{47}$.

Tak więc Lorenz wyklucza teleologię, czyli celowość ewolucyjnego rozwoju twierdząc, że jego bieg jest w całości wyznaczony przez przypadek, który przez działanie selekcji utrwala w określonych okolicznościach określone zmiany dziedzicznego wyposażenia. Dlatego sądzi, że można wykazać, iż ewolucja może biec $\mathrm{w}$ dowolnym kierunku $\mathrm{z}$ każdego stadium osiągniętego rozwoju, postępując ślepo za naciskiem selekcji. Pojęcie ukierunkowanej ewolucji nazywa „nienamysłowym sądem wartości” (unreflektiertes Werturteil). Droga

${ }^{45}$ T. Ścibor-Rylska, jw., s. $473-479$.

${ }^{46}$ K. Lore nz, Das Wirkungsgefüge..., s. $27 \mathrm{nn}$.

${ }^{47}$ Tamże, s. $24-30$; tenże, Der Abbau..., s. 25. 
do wyższych form zależy tylko od wewnętrznych i zewnętrznych przypadków ${ }^{48}$. Za M. Eigenem ${ }^{49}$ dzieje życia określa jako grę, w każdej nic nie jest stałe oprócz reguł gry ${ }^{50}$.

Najbardziej radykalną krytykę teleologii przeprowadza Wuketis. Za naczelną tezę Wuketisa można uznać twierdzenie, że procesy organiczne są bez wątpienia ukierunkowane celowo, natomiast nie dążą do celu ${ }^{51}$. Jego zdaniem filozofowie wiążą finalizm (teleologię) z ideą doskonalenia natury i z jej dążnością do coraz większej doskonałości. Wuketis określa tego rodzaju pogląd jako idealistyczne widzenie świata, jakọ wprowadzenie weń rządzącego światem nadprzyrodzonego czynnika. Wiąże się to z przyjęciem stwórczej zasady i uznaniem rozwoju za świadectwo istnienia Wszechmocnego Stwórcy. Jako zwolenników takiego ujęcia wymienia Wuketis m. in. E. Bechera, M. Hartmanna, Conrad-Martius, Telharda de Chardin, J. Illiesa i witalistów ${ }^{52}$.

Według Wuketisa dwie podstawowe myśli: myśl o ewolucji i myśl o ewolucji celowej są sprzeczne ze sobą. $Z$ tego dowolnie zresztą przyjętego twierdzenia wyprowadza wniosek, że ideę celowej ewolucji w przyrodoznawstwie mogą przyjmować tylko ci, którzy chcą pomieszać naukę z mistyką lub niebezpieczną ideologią. Łączenie mitów stworzenia, pisze, z przyrodniczą nauką o ewolucji może w efekcie dać tylko chaos. Przyrodoznawstwo nie jest kompetentne do odpowiedzi na pytanie o sens rozwoju i także stojąca we wzajemnych stosunkach z przyrodoznawstwem filozofia też nie jest stosowną instancją do tego ${ }^{53}$. Pojęcie sensu, powołującego czy nie powołującego się na przyrodoznawstwo, stanowi według Wuketisa coś treściowo pustego. Niebezpieczeństwo tej fałszywej według niego wiary, jakoby był gdzieś i kiedyś dany sens, polega na tym, że pozwala uwolnić się człowiekowi od każdej odpowiedzialności ${ }^{54}$. Wuketis powołuje się w tym względzie na St. Weinberga ${ }^{55}$, według którego im bardziej świat staje się zrozumiałym, tym bardziej okazuje się nam jako bezsensowny.

Człowiek może znaleźć sens i cel swego życia w samym sobie, przyznaje Wuketis, jednakże bez opierania się na jakimś ponadświatowym celu i bez trzymania się mniemań finalistów, reistów i mistyków. To, że wielu ludzi pozwala oszukiwać się politycznym i religijnym przywódcom wynika stąd, że nie są oni w stanie przeżyć własnej rzeczywistości w całej jej głębi. Dzieje się to zaś dlatego, że owi przywódcy czy uwodziciele dbają o to, by od dzieciństwa do starości wychowywać ludzi w niedojrzałości umysłowej. Tymczasem natura ist-

48 Tenże, Der Abbau..., s. 44, 52.

${ }^{49}$ M. Eigen, R. Winkler, Das Spiel. Naturgesetze steuern den Zufall, München-Zürich 1979 , s. $318 \mathrm{nn}$.

50 K. Lorenz, Der Abbau..., s. 61; tenże, Das Wirkungsgefüge..., s. 29.

${ }^{51} \mathrm{~F}$. Wuketis, Zustand..., s. 175.

52 Tamże, s. $153-155$.

53 Tamże, s. $155-157$.

54 Tamże, s. 158.

${ }^{55}$ S. W e in ber g, Die ersten drei Minuten, München-Zürich 1977, s. 212. 
nieje sama dla siebie. To, co rozgrywa się w ludzkim szaleństwie, nie dotyczy kosmosu. W potoku ewolucji natura sama stworzyła sobie cele ${ }^{56}$. Teleologia w sensie planującego Ducha jest nie do przyjęcia, ponieważ tylko człowiek może działać prawdziwie teleologicznie. Cała, jak się wyraża Wuketis, ,gadanina" o celowo ukierunkowanym porządku świata, o uprzednim założeniu rozwoju, należy do „zakurzonego kantoru” idealistycznej metafizyki ${ }^{57}$. Ogólny cel świata jest projekcją człowieka, który w swej niezaspokojonej tęsknocie wyszukuje w świecie fantazji ponadrzędne cele, oszukując i łudząc samego siebie $^{58}$.

Wuketis zdaje sobie sprawę $\mathrm{z}$ tego, że jego twierdzenia są narażone na zarzut sprzeczności. Z jednej bowiem strony zakłada, że wszechświat jest bezsensowny i bezcelowy, a z drugiej - że istoty żywe są skierowane do celu i człowiek odkrywa te cele. Wuketis odpowiada wymijająco, że mówienie o celach w nieorganicznym świecie jest zbędne, ponieważ kosmiczna ewolucja od prawybuchu opiera się na prawach natury, które powstały równocześnie z nim. Pytanie człowieka, dlaczego powstał świat i jego prawa, należy rozumieć psychologicznie, jako jego psychologiczną potrzebę. Otwarte przyznanie się, że „nie wiem”, jako odpowiedź na to pytanie, uważa Wuketis za uczciwsze, niż „rozwlekłe mówienie” o pierwszych przyczynach i ostatecznych celach świata. Tego rodzaju „gadaninę" uważa za desperackie chodzenie po omacku w ciemnościach, w których nie można oczekiwać żadnego światła ${ }^{59}$.

Za jedyne prawo rządzące światem, pisze Wuketis, na podstawie którego można wyprowadzać wniosek o końcu świata w dalekiej przyszłości, można uważać prawo entropii. Gdyby jednak ktoś chciał interpretować to prawo teleologicznie, to podlegałby złudzeniu. Śmierć cieplną świata, jako właściwy cel świata, mógłby wymyśleć tylko złośliwy demiurg. Byłoby skromniej przyznać, że świat zostanie skończony w dalekiej przyszłości z powodów tkwiących w nim samym. I tylko tyle może powiedzieć nam współczesna kosmologia. We współczesnym przyrodoznawstwie nic nie wskazuje, że świat służy jakiemuś celowi. O celu możemy mówić sensownie u żyjących organizmów, w których zachodzą procesy negentropiczne. Negentropia zgadza się, natomiast entropia nie zgadza się $\mathrm{z}$ teleologią ${ }^{60}$.

Jest to celowość, pisze Wuketis, służąca utrzymaniu gatunku. Zaprzeczać tej teleonomii byłoby przechodzeniem redukcjonistów obok istotnej cechy życia. Jednakże utożsamianie jej z teleologią byłoby przyznawaniem się do obskurantyzmu. Z drugiej strony sprowadzanie życia do nieorganicznych systemów byłoby zapoznaniem teleonomii organizmów. Właśnie przez teleonomię

\footnotetext{
${ }^{56} \mathrm{~F}$. Wuketis, Zustand..., s. $171 \mathrm{n}$.

57 Tamże, s. $173-175$.

58 Tamże, s. $177-178$.

59 Tamże, s. $178-179$.

60 Tamże, s. $179-180$.
} 
lepiej poznajemy życie poza mechanicyzmem i witalizmem, poza redukcjonizmem i metafizycznym holizmem. Ta wąska ścieżka wyprowadza nas z cieśni tradycyjnych kontrowersji o teleologię ${ }^{61}$.

Pytanie, jaki cel mógłby mieć kosmos, wymyka się spod każdego empirycznego badania. Tylko irracjonalna wiara mogłaby dać złudzenie, że świat jako całość jest skierowany do celu i jest rządzony przez opatrzność. Według Wuketisa wiara ta kryje w sobie wielkie niebezpieczeństwo, ponieważ posługują się nią różne ideologie. Zakładając bowiem ukierunkowany cel obejmujący cały świat, objęlibyśmy nim także człowieka, lecz przez to zwolnilibyśmy go od wszelkiej odpowiedzialności. W takiej ideologii dopatruje się Wuketis tendencji do ubezwłasnowolnienia człowieka i degradowania go do bezwolnego podmiotu, który musi ugiąć się przed wyższą prawidłowością, w interesie ideologów, którym mniej chodzi o dobro człowieka, niż o zaspokojenie swej mocy. Za słuszne uważa Wuketis słowa Lorenza ${ }^{62}$, że pojęcie uniwersalnej celowości oznacza absolutne zaprzeczenie człowieka jako rozumnej istoty ${ }^{63}$. Uniwersalne cele, konkluduje Wuketis, te „myślowe pajęczyny” wszelkich idealistycznie zorientowanych filozofów, należą do archiwum $^{64}$.

Wuketis tak reasumuje swoje wywody. Człowiek nie był z góry zaplanowany przez ewolucję. Bierzemy rozbrat $\mathrm{z}$ leibnizowską harmonią ustanowioną z góry. Rewidykowaną przez idealistyczną filozofię, a w następstwie przez różne ideologie uniwersalną celowość należy zdemaskować jako projekcje iluzyjnego myślenia. Człowiek może zakładać sobie przez swą refleksyjną świadomość cele i widzieć w nich nowe nadzieje ${ }^{65}$. Natomiast nie znajduje uzasadnienia przyjmowanie prawdziwej teleologii w przyrodzie, ponieważ w zakresie żyjących, przynajmniej w ramach branym na serio przyrodoznawstwie, nie możemy przyjmować „planujących duchów”66. Jednemu z paragrafów swej książki o ewoulucji, poznaniu i etyce daje tytuł: „pożegnanie z myślą o uniwersalnych celach"67.

Bardziej umiarkowanie wyraża się o teleologii K. E. Zimen. Według niego pojęcie teleologii pojawiło się z powodu braków w wyjaśnianiu naturalnej ewolucji. Dlatego są i będą ludzie, którzy będą się trzymać starego metafizycznego wyobrażenia o celowości, jako metafizycznej zasadzie, która kieruje rozwojem w kierunku uprzednio danego celu. Będą wierzyć, że istnieje teleologiczna zasada, zgodnie z którą ewolucja jest określona nie tylko przez łańcuch przyczyn sprawczych, lecz także przez dany a priori końcowy cel. Ostatecznym wyjaśnieniem tej celowości ma być planujący Duch, który kieruje wszelkie

${ }^{61}$ Tamże, s. $185-186$.

${ }^{62}$ K. Lorenz, Der Abbau..., s. 22.

${ }^{63} \mathrm{~F}$. Wuketis, Evolution..., s. $58 \mathrm{n}$.

64 Tamże, s. 57.

65 Tamże, s. 59.

66 Tenże, Biologische Erkenntnis..., s. 123 n.

${ }^{67}$ Tenże, Evolution..., s. 53. 
zdarzenia na określony cel. Jest to myśl o stwórczym planie. Wiary tej nie można ani udowodnić, ani jej zaprzeczyć. Rozwiązanie tej sytuacji widział Zimen w nowych odkryciach biologii 68 .

Parrot stawia sobie pytanie, czy poza światem istot żyjących obserwuje się fakty, które mogłyby być interpretowane w terminach celowości. Jest oczywistym, że poza dyskusją są maszyny stworzone przez człowieka, gdyż jako takie stoją poza biologiczną celowością. Próbując odpowiedzieć na to pytanie, Parrot wymienia przykładowo zasadę najmniejszego działania, prawo akcji i reakcji, prawa termodynamiki ii. W związku z tym nasuwa się dalsze pytanie, czy istnieje nieprzekraczalna granica między strukturami żywymi i nieożywionymi. Zdaniem Parrota istnieją takie fakty, które wskazują na istnienie takiej granicy. Są nimi stała walka przeciw entropii, wymiana materii, energii i informacji. Żyjące organizmy znajdują i stwarzają środki oraz sposoby postępowania, które są konieczne dla osiągnięcia celu. Parrot nie daje jednak jednoznacznej odpowiedzi na postawione na początku pytanie ${ }^{69}$.

Grassé reprezentuje pozytywne stanowisko wobec zagadnienia teleologii. Od Lamarcka aż do czasów dzisiejszych, pisze, biologowie stają stale przed dylematem, czy ewolucja jest procesem przypadkowym, czyli łańcuchem bez końca szczęśliwych przypadków, czy też jest poddana prawom i postępuje dokładnie ukierunkowanymi drogami. Według Grassé ewolucja nie posiada destruktywnego charakteru, jak się to jej ogólnie przypisuje. Ogólna tendencja do kompleksyfikacji i kreacji nowych systemów czy nowych gałęzi, wcale nie implikuje gaszenia starych form ${ }^{70}$. Głównym argumentem przypadkowej ewolucji jest właściwie jeden, mianowicie ten, że dziś nie obserwujemy w naturze żadnych innych dziedzicznych zmian poza spontanicznymi przypadkowymi mutacjami. Z faktu, że przypadkowe mutacje są dziedziczne wnioskują, że pomimo pozornej celowej kierunkowości musi się interpretować ewolucję jako wynik przypadków, których działanie koryguje selekcja. Dzięki niej przeżywają tylko korzystne warianty dla gatunku ${ }^{71}$.

Antyfinaliści sądzą, że ewolucyjna linia rozwoju sprawia wrażenie, jak gdyby była poddana wewnętrznej celowości, jednakże jest to tylko złudzenie. Naturalna selekcja działa permanentnie, adaptując indywidua i gatunki do otoczenia. Grassé stawia pytanie, jak można wierzyć w taką uniwersalną moc selekcji, skoro stwierdzamy, że w tym samym otoczeniu wspólżyją ze sobą gatunki archaiczne wraz z nowymi, z nich rozwiniętymi. Heterogeniczność fauny w tym samym biotopie byłaby niewyjaśnialna, gdyby selekcja posiadała nieograniczoną moc działalności. To nie biolog sprzeciwia się tej teorii, lecz zaprzeczają jej fakty. Paleontologia daje dowody, że ewolucja nie przebiega bezcelowo,

${ }^{68}$ K. E. Zi m e n, Strukturen der Natur, Frankfurt am Main 1973, s. $98-100$.

69 J. L. Pa r r o t, Quelques mots pour conclure, [w:] La fin et les moyens études..., s. 368 n. s. $60 \mathrm{n}$.

${ }^{70} \mathrm{P}$. P. G r a s sé, L'évolution biologique est-elle orientée?, [w:] La fin et les moyens études...,

${ }^{71}$ Tenże, Das Ich..., s. 31. 
lecz że posiada określone tendencje rozwojowe. Sito selekcji działa w sensie zasady antyprzypadkowej, działając finalizująco ${ }^{72}$.

Gdyby ewolucja była grą przypadku, to królestwo zwierząt stanowiłoby nieprzenikniony zamęt form, pomiędzy którymi nie można by było ustalić żadnych powiązań. A przecież nawet zwolennicy przypadku szukają pilnie rozwojowych linii według wzrastającej specjalizacji. Tak więc przeciwnicy celowej ewolucji w rzeczywistości wierzą w nią i nie wiedząc o tym, pracują zgodnie $\mathrm{z}$ tą zasadą ${ }^{73}$. Zdaniem Grasségo jeżeli przyjmie się wszechobecność i totipotencję naturalnej selekcji, to równocześnie akceptuje się integralną celowość biosfery. Grassé nazywa tę celowość faktyczną, względnie praktyczną. NaturaIna selekcja jest celowością w akcji, pracuje dla dobra gatunku, dla jego doskonalenia i przeżycia. Biokosmos jest poddany przez nią w swej całości najwyższej celowości królestwa żywych istot ${ }^{74}$. Ukierunkowanie ewolucyjnych linii rozwojowych ukazuje przeto immanentną celowość, której istnienie potwierdza także głębsza analiza tez, które uchodzą za antyfinalistyczne. Problem ten nie jest problemem metafizyki, ani mistycznej wiary, lecz jest to stwierdzenie oczywistego faktu, mianowicie ukierunkowania ewolucyjnych linii rozwoju ${ }^{75}$.

Istnienie immanentnej celowości w świecie biosfery nie musi prowadzić z koniecznością do uznania przyczyn celowych. Celowość immanentna jest czymś innym niż celowość transcendentna. Pierwsza jest sprawą biologii i należy do jej charakterystycznych właściwości, druga stanowi kategorię metafizyczną. Rozróżnienie to nie znaczy, że problem celowości transcendentnej w ogóle nie można stawiać w biologii, choć zajmuje się nią nie biolog, lecz metafizyk. Jednak przez to własna celowość makrokosmosu, jak i całego universum, wcale nie jest wykluczona ${ }^{76}$. Rozwiązaniu tego problemu przez współczesną biologię przeszkadzają przyjęte i spopularyzowane przez ideologię tezy, które lekceważą fakty. W nowej i wolnej od uprzedzeń atmosferze biologowie wraz z filozofami zaatakują pewnego dnia ten problem i pozwolą pojąć to, co stanowi pozaludzką transcendencję w przyrodzie ${ }^{77}$. Faktyczna celowość może wydawać się skromną w porównaniu do daleko sięgających celów transcendentnej celowości, której istnienia nie można zresztą nieodpracie udowodnić. Jednakże obiektywny i zobowiązany do prawdy biolog może ją stwierdzić i bierze ją pod uwagę, choć nie próbuje jej wyjaśnićc ${ }^{78}$.

\section{Wnioski}

W ostatnich dziesięcioleciach zmienił się sposób podchodzenia do zagad-

\footnotetext{
72 Tamże, s. 32 n.

73 Tamże, s. 30.

74 Tenże, L'evolution..., s. 71.

75 Tamże, s. 73.

76 Tenże, Das Ich..., s. $50-52$.

77 Tenże, L'evolution..., s. 74.

78 Tenże, Das Ich..., s. 45.
} 
nienia celowości w organizmach żywych. Do dawnych dyskusji filozofów włączyli się biologowie, co poszerzyło ramy zagadnienia i wskazało na nowe jego aspekty. Właśnie ze względu na biologię nie są dziś aktualne poglądy tych filozofów, którzy uważali, że nie można wykazać istnienia wewnętrznej celowości w organizmach żywych, które nie posiadają zmysłowego życia. Takie stanowisko zajmował np. ks. K. Kłósak, według którego z analizy bytu realnego i aktualnego nie można wyprowadzić na drodze dedukcyjnego wnioskowania tezy o sfinalizowaniu całej przyrody. Jego zdaniem nie możemy znaleźć w przyrodzie celów realizowanych od ich wnętrza i wysuwanych przez nią samą. Tego rodzaju cele nie mogą pojawić się tam, gdzie nie ma żadnego poznania i pragnienia. Byty pozbawione wszelkiego psychicznego życia mogą być jedynie od zewnątrz kierowane pośrednio lub bezpośrednio do określonych celów przez transcendentny dla nich umysł ${ }^{79}$.

Współczesny rozwój myśli biologicznej przesunął oś tego zagadnienia z pytania, czy istnieje celowość w organizmach żywych, na pytanie o jej zasięg w biosferze. Przyjęto powszechnie istnienie celowości w organizmach żywych na poziomie indywiduów i gatunków (teleonomia), natomiast istnieje spór o celowość ewolucji całej biosfery (teleologia). Ks. Kłósak jakby przeczuwał taki rozwój problematyki celowości, gdy swój artykuł zakończył stwierdzeniem, że pozostaje do zbadania, czy sfinalizowania całej przyrody nie dałoby się uzasadnić aposteriorycznie, na podstawie porządku empiriologicznego ${ }^{80}$.

Zachodzi pytanie, co sądzić o argumentach przeciwników teleologii? Wuketis, jeden z najzagorzalszych przeciwników teleologii, mówi o harmonii i porządku w organizmach, lecz równocześnie, podobnie jak i inni przeciwnicy teleologii, tłumaczy ten porządek działaniem przypadku. Przyjmując zasadę I. Prigogine, że nieporządek może czasem zrodzić porządek, twierdzi, że ewolucyjny rozwój biosfery jest dziełem przypadkowego porządkowania i kompleksyfikacji. Nie jest to jednak argument przekonywający. $\mathrm{Z}$ tego, że czasem w małym zakresie może przez przypadek powstać coś uporządkowanego, nie można logicznie wnioskować, że tak przebiegają wszystkie procesy natury. Zresztą, gdybyśmy przyjęli tak działający przez miliardy lat przypadek, prowadzący konsekwentnie do coraz wyższych i doskonalszych form, to logicznie musielibyśmy uznać tak działający przypadek za celową siłę kierującą rozwojem życia.

Przeciwnicy teleologii tłumaczą rozwój życia przypadkowymi mutacjami i selekcją. Znów zachodzi pytanie, czy przypadkowa mutacja tłumaczy wszystko? W kodzie genetycznym istnieją odcinki intron, które, jak przypuszczają biologowie, stanowią ewolucyjną rezerwę, która daje możliwości dalszego rozwoju. Przy transkrypcji odcinki te zostają usunięte nie przez mutacje, lecz

${ }^{79} \mathrm{~K}$. Kłós a k, Zagadnienie sfinalizowania przyrody a koncepcja bytu, [w:] Z zagadnień kultury chrześcijańskiej, Lublin 1973, s. $252-254$.

${ }_{80}$ Tamże, s. 254. 
przez wewnętrzne mechanizmy ${ }^{81}$. Ani mutacja ani selekcja nie biorą udziału w tych bardzo ważnych dla życia i przetrwania gatunku procesach. Słusznie pisze Grassé, że przypadkowe mutacje nie kierują rozwojem organizmu, lecz są wykorzystywane przez organizm dla dalszej ewolucji. Podobnie należy powiedzieć o selekcji. Ponad mutacją i selekcją stoi celowość, jako kierująca rozwo$j^{82}$. Hipoteza przypadku stanowi nie wyjaśnienie, lecz tylko ucieczkę przed wyjaśnieniem ogólnej celowości biosfery. Ponadto w dyskucjach nad przypadkiem brakuje rozróżnienia między przypadkiem absolutnym i względnym. Przypadek względny podaje tylko alternatywy dla selekcji i wcale nie sprzeciwia się celowości. Celowości sprzeciwia się przypadek absolutny. O tym przypadku Demokryt słusznie powiedział, że jest on złùdnym obrazem dla przykrycia własnej bezradności ${ }^{83}$.

Wuketis pisze, że teleonomia wyraża kierunkową działalność genetycznego programu, który powstał w historii ewolucji ${ }^{84}$. Ję̇eli jednak genetyczny program powstał w historii ewolucji, to znaczy, że dotyczy rozwoju całej biosfery, ukierunkowanej na powstawanie coraz wyżej zorganizowanych form życia, a zatem działała nie tylko teleonomia, lecz także teleologia. Wuketis zarzuca zwolennikom finalizmu (teleologii) obskurantyzm i ideologię, a tymczasem sam stawia twierdzenia dotyczące religii, filozofii i biologii, które nie posiadają podstawy ani w nauce ani w filozofii, lecz są wynikiem jego uprzedzeń, światopoglądu i ideologii. Wuketis uprawia nie biofilozofię, jak ją sam nazywa, lecz biomitologię.

Według Wuketisa przyjęcie teleologii byłoby równoznaczne z odmówieniem człowiekowi wolności woli i zwolnienia go od wszelkiej odpowiedzialności. Widzi w tym tendencje do bezwolnego podmiotu, który jest rządzony przez wyższą prawidłowość. Dziwnym jest rozumowanie Wuketisa, skoro sam mówi, że człowiek stwarza sam sobie cele, czyli stoi ponad nimi. Również dziwnym jest pogląd Wuketisa, gdy w przyjęciu teleologii widzi degradację człowieka do bezwolnego podmiotu i do ubezwłasnowolnienia, lub gdy za Lorenzem pisze, że pojęcie uniwersalnej celowości oznacza zaprzeczenie człowieka jako rozumnej istoty. Nie wiadomo, jaki logiczny związek, właśnie poza ideologią, widzą obaj autorzy w swych twierdzeniach. Przecież właśnie rozumem odkrywamy istnienie celowości w naturze.

Na poparcie tezy, że przypadek rządzi ewolucją, przytaczają Wuketis i Lorenz przypadki dysteleologii, do których zaliczają np. wymarcie dinozaurów w trzeciorzędzie. Nie jest to jednak naukowy dowód. Wymieranie gatunków było i jest spowodowane różnymi czynnikami zachodzącymi w środowisku. $\mathrm{Na}$

81 J. Argetsing e r-St e it z, Snurps: Helfer beim Entfernen sinnloser Genabschnitte, „Spektrum der Wissenschaft" $1988 \mathrm{nr} 8$ s. $84-89$.

82 P. P. Grassé, Das Ich..., s. 33.

83 Zob. H. S ach se, jw. s. 1 .

${ }^{84} \mathrm{~F}$. Wuketis, Evolution..., s. 57. 
lądzie ważnym w tym względzie jest klimat, a w środowisku morskim temperatura wody, stopień zasolenia i ilość rozpuszczonego tlenu w wodzie ${ }^{85}$. H. Fritzsch tłumaczy zjawisko wymarcia dinozaurów planetarną katastrofą, np. zderzeniem małego ciała niebieskiego z ziemią ${ }^{86}$. Ostatnio przypuszcza się, pisze J. M. Greenber, że trwający 29 milionów lat cykl uderzeń komet jest odpowiedzialny za wymarcie wielu gatunków, m. i. także dinozaurów ${ }^{87}$. S. M. Stanley podaje tabelę wymarłych w ciągu dziejów ziemi gatunków i przytacza wysuwane przez badaczy hipotezy ich wymarcia, a więc drastyczny wzrost lub spadek temperatury, chmury pyłu, zmiany położenia biegunów, a w związku z tym zmiany temperatury. Wysuwa się też hipotezę asteroidu, małej zimnej gwiazdy towarzyszącej naszemu słońcu, której przechodzenie co 26 milionów lat około słońca mogło zaburzyć tory komet i powodować uderzenie ich przez długi czas w ziemię. Nie jest pewnym, czy uda się nam w pełni zrozumieć przyczyny zmian klimatycznych ${ }^{88}$. Także człowiek niszczy przez swą działalność gatunki, co przecież nie jest dowodem braku celowości w przyrodzie. Wymieranie gatunków jest ubocznym skutkiem działania przypadku względnego i nie zawsze odpowiedzialnej czynności człowieka.

Przeciwnicy teleologii powołują się także na rzekome degeneracje i bezcelowe organella. Lecz i te twierdzenia nie zawsze znajdują potwierdzenie w nauce. J. M. Burchard, E. Irrgang i B. Andresen przytaczają pogląd wysuwany już przez Darwina, że małpie i ludzkie uszy stanowią końcowy produkt bardzo długiego rozwoju, a równocześnie są wzorcowym przykładem degeneracji. Tymczasem ostatnie badania wykazały wielką celowość budowy ludzkiego ucha. Zakręty, wypukłości i wklęsłości ucha podwajają fale akustyczne, tak że człowiek, jak zresztą i naczelne, posiada jak gdyby czworo uszu, co ma niemałe znaczenie dla mowy jako środka komunikacji ${ }^{89}$. Okazuje się, jak przedwczesne są sądy o degeneracji czy zbędności niektórych organelli i ich form, zarówno ludzkich jak i zwierzęcych.

$\mathrm{Z}$ poważną krytyką antyfinalizmu występuje A. Koestler. Według niego przyrodnik nie powinien bać się stosowania pojęcia celu, sensu i strategii ewolucji, gdyż pojęcia wcale nie mówią, że interweniuje tu „Boski Strateg”. Ta nieuzasadniona obawa zaciemniła jego zdaniem obraz dyskusji i zaprowadziła ortodoksyjnych teoretyków na pustynie sprzeczności. Taką sprzeczność widzi Koestler w poglądzie G. G. Simpsona, który uważa, że problem ewolucji rozwiązuje adaptacyjny mechanizm, który jest czynnikiem materialnym, gdy świadomy celu czynnik Stwórczy jest tak mistycznym pojęciem jak perpetuum

${ }^{85}$ D. M. Ra u p, S. M. St a nle y, Podstawy paleontologii, Warszawa 1984, s. 345.

${ }^{86}$ H. Fritz s ch, Vom Urknall zum Zerfall, München 1983, s. 280.

87 J. M. G re e nber, Aufbau und Entwicklung von interstellaren Staubkörnern, „Spektrum der Wissenschaft" 1984 nr 8 s. 91.

${ }^{88}$ S. M. St a n le y, Masensterben im Mer, ,Spektrum der Wissenschaft” 1984 nr 8 s. 92 - 101.

${ }^{89}$ I. A n d e r se n, Die Funktion der menschlichen Ohrmuschel, ,Spektrum der Wissenschaft" $1987 \mathrm{nr} 6$ s. $66-74$. 
mobile. Koestler podkreśla, że w rozumowaniu Simpsona zachodzi sofizmat pseudo-alternatywy: albo ewolucja jest bezcelowa, albo musi się przyjąć Stwórcę. W rzeczywistości, pisze Koestler, dążność do celu jest celowo ukierunkowaną wewnętrzną czynnością indywidualnych organizmów, niezależnie od tego, czy jest czy nie ma czynnika Stwórczego. Dążność do celu nie jest tym, co wprojektowywujemy w naturę i nie trzeba uważać jej za Boski czynnik, który miesza się do życia i utrzymuje go w biegu. Jest ona po prostu cechą biologicznego organizmu ${ }^{90}$.

Koestler wyraża zdziwienie, że przyrodnik mówi o celu czy ukierunkowaniu na cel w ontogenezie, natomiast uważa za kacerstwo stosowanie tego pojęcia do filogenezy. Zgodnie $\mathrm{z}$ tego rodzaju poglądem ontogeneza jest ukierunkowana na cel, natomiast filogeneza jest ślepa, ontogenezę cechuje uczenie i pamięć, natomiast filogeneza jest pozbawiona obu tych czynników. Neodarwiniści próbują przekroczyć te niezgodności przez przyjęcie teleonomii. Skoro jednak ontogeneza, pisze Koestler, jest ukierunkowana celowo, to trudno zrozumieć, dlaczego całość ontogenez miałaby być bezcelową. Suma ontogenez oddaje czynne dążenie istot żyjących do możliwie największego wyczerpania rozwojowego potencjału planety ${ }^{91}$. Ukierunkowanie na cel wszystkich żywych organizmów, strategia genów i siła eksploratywnego pędu u zwierząt i ludzi wskazuje na to, że przyciąganie przez przyszłość jest tak samo realne, jak nacisk przeszłości. Przyczynowość sprawcza i celowa stanowią komplementarne zasady nauki o życiu. Jeżeli wyłączymy celowość, to wyłączymy życie i z biologii i z psychologii ${ }^{92}$.

Jak z powyższego wynika, mamy do wyboru dwie alternatywy: albo świat jest bezcelowy i bezsensowny, rządzony ślepym przypadkiem, albo świat jest ukierunkowany do realizowania coraz wyższej doskonałości i wolności. Jeżeli organizmami rządzi celowość, to trudno zrozumieć, jak ukierunkowaniem ku wyższej doskonałości może rządzić przypadek. Teleologia jest logicznym wnioskiem $\mathrm{z}$ teleonomii. Trudno bowiem zrozumieć, jak celowo ukierunkowane organizmy mogą przez przypadek stanowić spójny ewolucyjny ciąg rozwojowy ku coraz wyższym formom. Jeszcze trudniej zrozumieć twierdzenie Wuketisa, że teleonomia i teleologia są sprzeczne ze sobą. Jak rośnie stopień swobody działania wraz z powstawaniem coraz wyższych form, tak wzrasta wewnętrzna celowość od nieświadomej do świadomej u człowieka.

Rozumowanie Wuketisa, Lorenza ii. przeciwników teleologii można przez analogię przyrównać do rozumowania, że w ciągu liczb naturalnych każda $\mathrm{z}$ nich posiada swoje znaczenie, natomiast ich ciąg stanowi przypadkowy bezsensowny związek. Ewolucyjny ciąg organizmów stanowi szereg gatunków powiązanych wzajemnym pokrewieństwem, a nie jest przypadkowym zlepkiem

${ }^{90}$ A. Koest le r, Der Mensch - Irrläufer der Evolution, Bern-München 1978, s. 246-248.

91 Tamże, s. 248.

92 Tamże, s. 263. 
poszczególnych organizmów. Tak jak w poszczególnych organizmach, tak i w całym ewolucyjnym szeregu istnieje wewnętrzna celowość. Reasumując trzeba powiedzieć, że przyjmowanie teleonomii a odrzucanie teleologii jest oparte nie o naukę, lecz o ideologiczne uprzednie założenia.

Rozważanie całej biosfery z punktu widzenia celowości zrodziło myśl spojrzenia na ewolucję „od góry”, co wyraziło się w postaci antropicznej zasady. Biolog zanurzony w analizę poszczególnych procesów życia zatraca widzenie całości. Inaczej przedstawia się problem widziany od góry przez rozumnego obserwatora, którym jest człowiek. Fakt istnienia człowieka ograniczał przebieg ewolucji, wykluczając pewne możliwości, które uniemożliwiłyby jego pojawienie się na widowni dziejów. Kosmos i biosfera musiały być ukierunkowane na powstanie rozumnej istoty. Wyraża się to w słabym sformułowaniu antropicznej zasady: Ponieważ w naszym świecie jest dany obserwator, przeto wszechświat musiał posiadać takie własności, które umożliwiły zaistnienie takiego obserwatora ${ }^{93}$.

Okazuje się, pisze R. Breuer, że wiele cech natury dopiero wtedy stają się jasne, gdy uwzględni się fakt istnienia człowieka. Antropiczna zasada pozwoliła jego zdaniem po raz pierwszy przebadać przyrodniczy obraz świata w jego wewnętrznej spójności i odkryć powiązania pomiędzy trzema dziedzinami: podstawowymi prawami natury, przebiegiem ewolucji oraz istnieniem inteligentnego obserwatora ${ }^{94}$. Za F. J. Dyson powtarza, że nie byłoby niespodzianką, gdyby się okazało, że początek i los energii w świecie nie może być całkowicie zrozumiany w izolacji od zjawiska życia i świadomości. Jako konkluzję Breuer wyprowadza wniosek, że była to jedynie możliwa droga, która prowadziła od prawybuchu do inteligentnej istoty ${ }^{95}$.

Niezależnie od tego, czy antropiczna zasada znajduje czy nie znajduje uznania wśród biologów, jedno jest pewne, że rozpatrywanie izolowanych procesów natury nie pozwala na pełne ich wyjaśnienie. Musimy tu odwołać się do „perspektywy nosa"96. Zanurzając się w analizę poszczególnych procesów w organizmach, tracimy widzenie całości, w naszym przypadku tracimy widzenie ogólnej celowości życia. Tymczasem całość jest czymś więcej niż sumą części, a więc całość biosfery jest czymś więcej niż prostą sumą teleonomii. Tym „więcej” jest teleonomia, czyli wewnętrzna celowość całej ewolucji życia.

${ }_{93}$ R. B r e u e r, Antropische Prinzip, Frankfurt-Berlin-Wien-Ullstein 1984, s. $17-24$.

94 Tamże, s. 26.

95 Tamże, s. 238; zob. P. Lüth, Der Mensch ist kein Zufall, Frankfurt am Main 1984, s. 157.

${ }^{6}$ Zob. T. S. W o j ci e ch ow sk i, Z problematyki stosunku teorii ewolucji do wiary, „Studia Philosophiae Christianae" $23: 1987$ s. 1, 191. 


\section{AUS DER PROBLEMATIK DER FINALITÄT IN DER BIOLOGIE}

\section{Zusammenfassung}

In der Biologie des 20. Jahrhunderts hat man erneut die Diskussion über die Bedeutung der Finalität in dem Bereich der lebendigen Organismen begonnen. Man fing an zu begreifen, dass der Zweckgesichtspunkt in der Biologie eine wesentliche Rolle in der Erklärung der lebendigen Prozesse spielt. Jedoch begreift man die Finalität auf zweifache Weise: als Teleonomie, die nur im Bereich der einzelnen Organismen und Gattungen ihre Anwendung hat, und als Teleologie, die alle Lebewesen umfasst. Die Teleonomie ist beinahe von allen Biologen angenommen, nicht aber die Teleologie. Die Ansichten über die Teleologie unterscheiden sich grundsätzlich. Die einen schreiben der Teleologie, die anderen dem Zufall die lenkende Rolle zu in der Evolution der ganzen belebten Natur. Die Argumentation der ersten scheint mehr überzeugend zu sein, als die der Gegner der Teleologie. 